\title{
Imagining the Nation throughout School History Master Narratives
}

Questions regarding how people construct historical narratives in current societies have taken center stage in recent public and academic discussions, particularly since the seminal work on nations as "imagined communities". ${ }^{1}$ The master narrative has been developed as a unit of analysis in current social scientific and historical thought. Heller describes master narratives as general interpretation patterns. ${ }^{2}$ Their function is making sense of the past, present and future of a cultural community. The importance of this topic is reflected in many current political debates that are characterized by their increased "historisation". ${ }^{3}$ Billig refers to how politicians invoke events of national history in order to meet their political agendas. ${ }^{4}$ Analyses of school history contents, from the perspective of the history discipline ${ }^{5}$ or from the history education point of view, ${ }^{6}$ reveal their close resemblance to "official narratives" that aim at historically legitimizing the present and future political agenda. In relation to master narratives and associated historical representations intense debates are taking place about the kind of historical contents that should be taught. What history should be transmitted in schools and through Museums, TV series and other formal and informal educational devices, is under discussion. ${ }^{7}$ These debates starting in the mid 1990s are still carried on in many countries. The salience and significance of this issue is revealed in the

1 Benedict Anderson, Imagined communities: reflections on the origin and spread of nationalism (London: Verso, 1991).

2 Agnes Heller, European master narratives about freedom, $u$ in Handbook of contemporary European social theory, ed. Gerard Delanty (New York, NY: Routledge, 2006).

3 Anouk Smeekes, The presence of the past. Historical rooting of national identity and current group dynamics (Doctoral dissertation, Utrecht University, 2014).

4 Michael Billig, Banal Nationalism (London: Sage, 1995).

5 Stefan Berger, "De-nationalizing history teaching and nationalizing it differently! Some reflections on how to defuse the negative potential of national(ist) history teaching," in History education and the construction of national identities, eds. Mario Carretero, Mikel Asensio, and Marof national identi (Charlotte, NC: Information Age Publishing, 2012).

6 Stuart Foster, "Re-thinking historical textbooks in a globalized world."ing History Education and the Construction of National Identities, eds. Mario Carretero, Mikel Asensio, and Maronal Identitiescal (Charlotte, CT: Information Age Publishing, 2012).

7 Peter Seixas, “National history and beyond,” Journal of Curriculum Studies 41, no. 6 (2010).

Ә Open Access. (C) 2018 Mario Carretero, published by De Gruyter. (c) BY-NC-ND This work is licensed under the Creative Commons Attribution-NonCommercial-NoDerivatives 4.0 License.

https://doi.org/10.1515/9783110466133-006 
"History Wars" sustained in numerous societies throughout the last decade (see Carretero 2011, Taylor and Guyver 2011). ${ }^{8}$

History Wars have led to the revision of the historical narratives in which, as Hobsbawm said, "the nation is invented"9 (see also Berger, Eriksonas and Mycock $2008^{10}$ ). Research conducted in several countries in the last ten years has documented how the production of school historical narratives is closely related to the construction of national discourses ${ }^{11}$ Interestingly, this revision of historical narratives coincides with, and probably originates from, the intensification of the globalization process and its social, political and economic effects. Profound transformations such as the crisis of political identities, the emergence of new discussions about nationalism and giving new significance to the question "who are we" affect the history that is taught to young people in any society. In the European Union, for example, several countries have undertaken a reinterpretation of the 'national histories' taught in schools in light of the need to promote the idea of a common future. ${ }^{12}$ These different cases reveal intellectual and educational movements in which a reconsideration of the past is emerging, favouring the profound revision of national and local histories both at the academic level and at the school level.

\section{Tensions in History Education and their effects on representation}

Building upon and extending this tradition of research a new and important line of questioning has emerged: How do the conflicting narratives found in academic and public debates and in school textbooks, manifest in students' minds? How do the characteristic features of the social production of historical narratives

8 Mario Carretero, Constructing Patriotism. Teaching History and Memories in Global Worlds (Charlotte, CT: Information Age Publishing, 2011).

Tony Taylor and Robert Guyver,,History Wars and Robert Guyver ,, 2011 tory and Memorie(Charlotte, North Carolina: Information Age Publishing, 2011).

9 Eric Hobsbawm, Nations and nationalism since 1780: Programme, myth, reality (Cambridge: Cambridge University Press, 1990).

10 Stefan Berger, Linas Eriksonas, and Andrew Mycock, eds., Narrating the nation: Representings in history, media and the arts (New York, NY: Berghahn Books, 2008).

11 Bruce VanSledright, "Narratives of nation-state, historical knowledge and school history education, a Review of Research in Education 32, no. 1 (2008).

12 Maria Grever and Siep Stuurman, eds., Beyond the canon: History for the 21st century (Basingstoke, UK: Macmillan, 2007). 
translate into the processes of individual consumption of historical narratives? Our empirical work expands on this last line of inquiry. ${ }^{13}$

For these issues considering the objectives of History Education is necessary, as they contribute to the construction and imagination of the nation. Different researchers have considered the existence of competing objectives of school history. ${ }^{14}$ Carretero ${ }^{15}$ (see also Carretero and Bermudez 2012 ${ }^{16}$ ) has redefined these objectives as "romantic" and "enlightened", because their features and functions stem from their respective intellectual roots in Romanticism and the Enlightenment. In other words, it is supposed that history has been taught in all national school systems attending to two different -and to some extent contradictory- goals: to make students "love their country"17 and to make them "understand their past". ${ }^{18}$ In a romantic vein, history education is a fundamental strategy used to achieve: (a) a positive assessment of the past, present and future of one's own social group, both local and national, and b) an identification with the country's political history. In an enlightened vein, fostering critical citizens capable of informed and effective participation in the historical changes of both the nation and the rest of the world has been aimed at. This can include the criticism of the own local or national community, or even larger political units. In their more recent manifestation in several countries, enlightened goals translate into the following disciplinary and cognitive objectives: (a) to understand the past in a complex manner, which usually implies mastering the discipline's conceptual categories ${ }^{19}$; (b) to distinguish different historical periods, through the appropriate adequate comprehension of historical time (Barton, 2008); (c) to

13 Mario Carretero and Floor van Alphen, "Do master narratives change among high school students? A characterization of how national history is represented," Cognition and Instruction 32, no. 3 (2014), doi: 10.1080/07370008.2014.919298.

14 Keith C. Barton and Linda S. Levstik, Teaching History for the Common Good (Mahwah, NJ: Lawrence Erlbaum Associates, 2004).

Sam Wineburg, Historical Thinking and Other Unnatural Acts (Philadelphia: Temple University Press, 2001).

15 Mario Carretero, Constructing Patriotism. Teaching History and Memories in Global Worlds (Charlotte, CT: Information Age Publishing, 2011).

16 Mario Carretero and Angela Bermudez, "ario Carretero and Angela BeOxford Handbook of Culture and Psychology, ed. Jaan Valsiner (Oxford: Oxford University Press, 2012).

17 Martha C. Nussbaum and Joshua Cohen, eds., For Love of Country?: A New Democracy Forum on the Limits of Patriotism (Boston, MA: Beacon Press, 2002).

18 Peter Seixas, ed., Theorizing historical consciousness (Toronto: University of Toronto Press, 2004).

19 Mario Carretero and Peter Lee, rLearning Historical Concepts.e in Handbook of Learning Sciences, 2nd ed., ed., Keith Sawyer (Cambridge: Cambridge University, 2015). 
understand historical multi-causality and to relate the past with the present and the future ${ }^{20}$; and (e) to approach the methodology used by historians. ${ }^{21}$

These romantic and enlightened goals of history education have coexisted from the very beginning of school history teaching and developed over time. The romantic goals were the most important from the nineteenth century until approximately 1960. Even nowadays they are the only goals of History Education in a number of countries. Therefore, national histories "were born to be taught". They are contained in a variety of records such as museums, ${ }^{22}$ monuments and patriotic celebrations.

Patriotic rituals and heritage celebrations play an important role in many countries. ${ }^{23}$ After the 1960 s and 1970s, the disciplinary goals started to have an increasing importance. ${ }^{24}$ When enlightened goals were included as part of the historical contents they were considered perfectly compatible with the romantic objectives. However, several studies have indicated the tension this might generate in students' minds. ${ }^{25}$ In this vein, it is essential to clarify how this tension is affecting the understanding of historical contents, and how the romantic goals of history instruction might hinder the comprehension of a more complex and disciplinary history. This becomes particularly clear in colonial and postcolonial history teaching. Spanish school textbooks have traditionally omitted essential issues in the American colonization such as the subjugation of indigenous people or slavery as a generalized social and economic practice. ${ }^{26}$ Therefore, it could be said that aiming at loving the Spanish country has had serious consequences for understanding its colonial past. In contrast, these colonial issues are highlighted in Mexican

20 Barton and Levstik, Teaching History for the Common Good.

21 Chaunces Monte-Sano, hDisciplinary Literacy in History: An Exploration of the Historical Nature of Adolescents' Writing, isJournal of the Learning Sciences 19, no. 4 (2010).

22 Simon Knell, Peter Aronsson, and Arne Bugge Amundsen eds., National Museums. New Studies from around the World (London: Routledge, 2011).

23 Mario Carretero, Constructing Patriotism.

Joel Westheimer, Pledging allegiance: The politics of patriotism in America's schools (New York: Teachers College Press, 2007).

24 Carretero and Bermudez, Constructing Histories.

25 Cesar Lopez, Mario Carretero, and María Rodriguez-Moneo, “Telling a national narrative that is not your own. Does it enable disciplinary historical consumption?” Cultuture \& Psychology 20, no. 4 (2014).

26 Todorov, Tzvetan. The conquest of America: The question of the other (New York: Harper and Collins, 1999).

Marc Ferro, The use and abuse of history: Or how the past is taught to children. London: Routledge. New and revised edition in French (Paris: Press Universitaires de France, 1984-2002) (vgl. Kommentar in Bibliographie (SB)) 
or Brazilian textbooks. ${ }^{27}$ Similar findings are reported when former colonizer and colonized countries are compared in France/Algeria, Great Britain/India, China/ $J^{J a p a n}{ }^{28}$ and Japan/Korea (The Academy of Korean Studies, 2005). These tensions are not only a matter of controversial issues in recent history, but remote history matters are really at the bottom. That is, the historical issues at the roots of national identity construction are a fundamental part of the problem. For this reason, it can be said that even nowadays historical master narratives are playing an important role in the imagination of the nation. They serve the romantic goals of history education particularly well. And their influence is becoming more widespread and more intense in the emergence of new nationalisms in Europe and other parts of the world. As Alridge ${ }^{29}$ and Straub ${ }^{30}$ have indicated, these "master narratives" pervade underneath a variety of specific contents and through time. While specific narratives may change frequently, these underlying master narratives rarely change, and manifest once and again in subsequent revisions of history contents.

In American textbooks the vast majority of national narratives are organized around the concepts of progress and freedom and students reuse these motifs to explain past events. ${ }^{31}$ Thus the resistance of Native Americans to the waves of European settlement is seen as an obstacle to achieve progress. In a similar vein, the Spanish master narrative is based on the Reconquest and the expulsion of the Muslims (Alvarez Junco, 2011). ${ }^{32}$ National narratives raise certain questions as to what happens when people identifying with the 'other' in these narratives have to appropriate them. How do immigrants and minority groups receive and appropriate school historical knowledge in general and master narratives in particular? In Spain, a country with much Latin American immigration, the American colonization is represented in a very positive way. ${ }^{33}$ How does this affect a migrant's representation? And how do national master narratives, in the societies where the immigrants come from, present historical developments, particularly in relation to colonization process? So far there are hardly any studies about these issues, even though the immigration process has intensified. In

27 Mario Carretero, Liliana Jacott, and AsuncióMario Carretero, Liliana Jacott, and Asunciextbooks: are Mexican and Spanish students taught the same story?"xLearning and Instruction 12, no. 6 (2002).

28 Ferro, use and abuse of history.

29 Derrick P. Alridge, "The limits of master narratives in history textbooks: An analysis of representations of Martin Luther King, Jr.” Teachers College Record, 108 (2006).

30 JDerrick raub, ed., Narration, identity, and historical consciousness (New York, NY: Berghahn Books, 2005).

31 Barton and Levstik, Teaching History.

32 Carretero, Constructing Patriotism.

33 Carretero, Jacott, and L and ero, JacLearning history through textbooks. 
Europe, for example, contemporary political debates demonstrate an increased "historisation" of national citizenship. ${ }^{34}$ Politicians stress the need for citizens, both migrants and natives, to gain more knowledge of the national heritage. They claim that increased knowledge of national heritage will lead to a much-needed community cohesion in today's globalized societies. ${ }^{35}$ Nevertheless, the implications of that knowledge for the inclusion of migrants and for intergroup relations in multi-cultural societies are dubious. That is, until a more complete picture of how historical knowledge is represented by immigrant citizens is drawn.

Uncovering a new angle on master narrative representation, Wineburg's study on the cross-generational communication about the Vietnam War shows the production of a national rhetoric that homogenizes popular views despite the complexities of the lived past. In the context of the European Union, Welzer, Moller \& Tschuggnall (2002) have studied how different generations make sense of the Nazi era and the Holocaust. They present fascinating discourse and cognitive analyses about how collective memories could include sophisticated ways of historical denial. Recent international conferences (http://www.schoolxmemory.eu/) demonstrate a heightened interest in school and family memories and the necessity to studying generational influences. Unfortunately, there are hardly any studies about generational transmission concerning historical master narratives in the context of immigration, even though very relevant questions can be asked that could clarify the relation between history representation and national identity. How do first, second and third generation migrants coincide or differ in their take on national histories of the countries of origin and destination? Do conflicts arise between generations in their representation? Or is there homogenization between them and a conflict with other groups' historical representations? More in general, studying generational transmission, immigration and the colonization's influence on history representation might further clarify the tensions involved in imagining the nation.

\section{The contributions of collective memory and social and cultural psychology studies}

From the perspective of socio-cultural psychology, official narratives on the nation's origin constitute cultural tools that configure schematic templates in

34 Smeekes, Presence of the past.

35 Jan W. Duyvendak, The politics of home: belonging and nostalgia in Western Europe and the United States (Basingstoke: Palgrave Macmillan, 2011). 
the minds of students. ${ }^{36}$ Schematic templates define the underlying structure of historical narratives and of the understanding people have of these narratives. National master narratives have been primarily studied in the context of their production, that is, in history textbooks and in other cultural devices related to the public uses of history. ${ }^{37}$ Much less work has been done on how exactly students “consume" master narratives (Wertsch \& Rozin, 2000). Importantly, the process of learning or consumption is more than a passive reproduction of the produced educational content. Rather, it is actively appropriated and processes of resistance, expressed by counter narratives, have been found to occur. ${ }^{38}$

Present research has shown three key characteristics of these national narratives. ${ }^{39}$ First, the nation and nationals are established as the main historical subjects of these narratives. They are displayed as if they were timeless and static entities and encountered throughout history. Second, the actions of the national group are always judged morally positive in contrast to foreign actions. In other words, the past is presented in an ethnocentric, biased manner. Finally, a conflict over a national territory, that stresses its supposed atemporal connection to the nationals, is one of the narrative's main themes. ${ }^{40}$ The key paradox is that this common national identity - which constitutes the subject of national narratives - that is meant to bind people in the past and the present even includes events from the past in which the nation and the nationals did not exist at all. This misconnection between the past and present creates a misunderstanding of the nation and national identity. As Billig coined it, it creates beliefs based on a "banal nationalism". 41

Research on social psychology and collective memory has stressed the importance of history perceptions in shaping national identity. ${ }^{42}$ The contents of collective memory, ${ }^{43}$ transmitted from one generation to another, are collective constructs that within a given society define rights and obligations, legitimize

36 James V. Wertsch, Voices of Collective Remembering (Cambridge: Cambridge University Press, 2002).

37 Alridge, Limits of master narratives.

38 Wertsch, Voices of Collective Remembering.

39 see Carretero and Bermudez, Constructing Histories.

40 Cesar Lopez, Mario Carretero, and María Rodriguez-Moneo, "Conquest or reconquest? Students'onquest or reconquest? Stuedded in a historical narrative," Journal of the Learning Sciences (2014).

41 Billig, Banal Nationalism.

42 Stephen Reicher and Nick Hopkins, Self and nation: Categorization, contestation and mobilisation (London: Sage Publishing, 2001).

43 Maurice Halbwachs, On collective Memory, ed. and trans. Lewis A. Coser (Chicago: University of Chicago Press, 1992). 
political agreements and determine right and wrong actions according to historical experience. ${ }^{44}$ This research is therefore consistent with social identity and cognition theories, which postulate that people who define themselves in terms of their membership in a specific group are motivated to evaluate their group positively (Tajfel \& Turner, 1986). This national identification connects the feeling of self-esteem to in-group esteem and establishes a cultural continuity between past and present. The result is a simplified understanding of history that is skewed favorably toward one's national group and exclusive to the 'other' (Barreiro, Wainryb \& Carretero, 2015; Kadianaky, Eleni \& Carretero, in press). Furthermore, a number of studies focuses on how for example the history of colonialism, slavery and genocide leads to group-based emotions (i.e. collective guilt, shame) and how historical events like these relate to attitudes towards intergroup relations (i.e. attitudes of compensation). There is also a reverse focus, namely on the 'victims' of conflict and on their group-based emotions (i.e. collective victimhood) and their attitudes towards intergroup relations (e.g. Bar-Tal, ChernyakHai, Schori \& Gundar, 2009).

\section{Cognitive change of historical concepts and narratives}

Finally, considering research on cognitive development and conceptual change processes is also fruitful, because learning processes and conceptual abilities seriously affect how school historical contents are represented throughout school experiences. Research on conceptual change has received much attention in the last decades. It is important for capturing the process of change from intuitive and everyday knowledge to complex and expert knowledge (Vosniadou, 2013). In this field, initially focused on natural scientific knowledge, there has been increased attention to social scientific and historical. Our research group ${ }^{45}$ has developed an argument on how the work of Koselleck ${ }^{46}$ on the change of historical

44 Chris S. Sibley, James H. Liu, John Duckitt, and Sammyh S. Khan, "Social representations of history and the legitimation of social inequality: The form and function of historical negation," European Journal of Psychology 38, no. 3 (2008).

45 Mario Carretero, Jose A. Castorina, and Leonardo Levinas, "Conceptual change and historical narratives about the nation. A theoretical and empirical approach," in International Handbook of Research on Conceptual Change, 2nd ed., ed., Stella Vosniadou (New York: Routledge, 2013).

46 Reinhart Koselleck, Futures past: On the semantics of historical time (New York, NY: Columbia University Press, 2004). 
concepts could illuminate cognitive change research on history concepts. The argument establishes a relation between the change of concepts throughout different historical periods and conceptual change across cognitive and social development of individuals and social groups. Cognitive and educational studies have analyzed how students develop core historical concepts (Barton, 2008). ${ }^{47}$ As it was stated before, historical narratives have been studied as to their contributing role in the construction process of national and cultural identities (Hammack, 2011). ${ }^{48}$ However, this kind of narratives, apart from involving a number of events in relation to a story, also contain social, political and historical concepts. These concepts can refer to either rather concrete social objects and problems or to abstract ones (see Box 6.1). Our studies show that historical concepts such as nation, revolution and independence are expressed within the framework of the general structures provided by master narratives. ${ }^{49}$ Therefore, students use a concept to construct a narrative and, at the same time, that narrative expresses the concept itself. Concepts thus play a double role in historical narratives. On one level of analysis they are tools for building narratives, giving them meaning and direction. At the same time the characteristics of the concepts are developed through the narratives, which contextualize and particularize them.

Box 6.1: Dimensions of Analysis for Master Narratives

\begin{tabular}{ll}
\hline Narrative Dimensions & Main questions and analytic categories \\
\hline Historical and & $\begin{array}{l}\text { Who is the main voice of the narrative? Which groups are } \\
\text { represented? That is, what inclusion/exclusion process is going } \\
\text { on? How does the selection of the subject influence the whole } \\
\text { narrative? Is the national subject a timeless one? } \\
\text { Identification Process }\end{array}$ \\
$\begin{array}{l}\text { Which group do the participants identify with? Do they apply a } \\
\text { "we" versus "them" structure? Do the "we" and "they" belong to } \\
\text { the present or to the past or to both? } \\
\text { Main Historical Figures } \\
\text { Who are the main figures? How are they conceived and valued? } \\
\text { Are they considered in their social and historical context or just } \\
\text { as individual quasi mythical characters? Are they presented as } \\
\text { heroes? }\end{array}$ \\
\hline
\end{tabular}

(continued)

47 Mario Carretero and Peter Lee, "Learning Historical Concepts," in Handbook of Learning Sciences, 2nd ed., ed. Keith Sawyer (Cambridge: Cambridge University, 2015).

48 Phillip L. Hammack, Narrative and the politics of identity: The cultural psychology of Israeli and Palestinian youth (New York, NY: Oxford University Press, 2011).

49 Mario Carretero, Mikel Asensio, and Marik Rodríguez-Moneo, eds. History Education and the Construction of National Identities (Charlotte, CT: Information Age Publishing, 2012). 
Box 6.1: (continued)

\begin{tabular}{ll}
\hline Narrative Dimensions & Main questions and analytic categories \\
\hline Main Topic of the Narrative & $\begin{array}{l}\text { What is the main goal of the narrative? I.e., searching for freedom, } \\
\text { defending the national or local interests? Is this goal considered } \\
\text { in a complex historical context or in a simple and anecdotic way? } \\
\text { What kind of moral and civic values are displayed in the } \\
\text { narratives? How do these values apply to different national } \\
\text { groups? }\end{array}$ \\
$\begin{array}{l}\text { Nation \& National Identity } \\
\text { Conceptions }\end{array}$ & $\begin{array}{l}\text { Are these conceptions socially constructed or naturalized? Is } \\
\text { national identity viewed as a timeless entity? }\end{array}$ \\
\hline
\end{tabular}

\section{Literature cited}

Alridge, Derrick. P. The limits of master narratives in history textbooks: An analysis of representations of Martin Luther King, Jr. Teachers College Record, 108 (2006): 662-686.

Anderson, Benedict. Imagined communities: reflections on the origin and spread of nationalism, rev. ed. London: Verso, 1991.

Barton, Keith C. and Linda S. Levstik. Teaching History for the Common Good. Mahwah, N): Lawrence Erlbaum Associates, 2004.

Berger, Stefan. De-nationalizing history teaching and nationalizing it differently! Some reflections on how to defuse the negative potential of national(ist) history teaching. In History education and the construction of national identities, edited by Mario Carretero, Mikel Asensio, and María Rodríguez-Moneo, 33-47. Charlotte, NC: Information Age Publishing, 2012.

Berger, Stefan, Linas Eriksonas, and Andrew Mycock, eds. Narrating the nation: Representings in history, media and the arts. New York, NY: Berghahn Books, 2008.

Billig, Michael. Banal Nationalism. London: Sage, 1995.

Carretero, Mario. Constructing Patriotism. Teaching History and Memories in Global Worlds. Charlotte, CT: Information Age Publishing, 2011.

Carretero, Mario, Mikel Asensio, and María Rodríguez-Moneo, eds. History Education and the Construction of National Identities. Charlotte, CT: Information Age Publishing, 2013

Carretero, Mario and Angela Bermudez. Constructing Histories. In Oxford Handbook of Culture and Psychology, edited by Jaan Valsiner, 625-646. Oxford: Oxford University Press, 2012.

Carretero, Mario, Jose A. Castorina, and Leonardo Levinas. Conceptual change and historical narratives about the nation. A theoretical and empirical approach. In International Handbook of Research on Conceptual Change, 2nd ed., edited by Stella Vosniadou, 269-287. New York: Routledge, 2013.

Carretero, Mario, Liliana Jacott, and Asunción López-Manjón. Learning history through textbooks: are Mexican and Spanish students taught the same story?. Learning and Instruction 12, no. 6 (2002): 651-665. 
Carretero, Mario and Peter Lee. Learning Historical Concepts. In Handbook of Learning Sciences, 2nd ed., edited by Keith Sawyer, 587-604. Cambridge: Cambridge University, 2015.

Carretero, Mario and Floor van Alphen. Do master narratives change among high school students? A characterization of how national history is represented. Cognition and Instruction 32, no. (2014): 290-312. doi: 10.1080/07370008.2014.919298.

Duyvendak, Jan W. The politics of home: belonging and nostalgia in Western Europe and the United States. Basingstoke: Palgrave Macmillan, 2011

Ferro, Marc (1984-2002). The use and abuse of history: Or how the past is taught to children. London: Routledge. New and revised edition in French, Paris, Press Universitaires de France

Foster, Stuart. Re-thinking historical textbooks in a globalized world. In History Education and the Construction of National Identities, edited by Mario Carretero, Mikel Asensio, and María Rodríguez-Moneo, 49-62. Charlotte, CT: Information Age Publishing, 2012.

Grever, Maria and Siep Stuurman, eds. Beyond the canon: History for the 21st century. Basingstoke, UK: Macmillan, 2007.

Halbwachs, Maurice. On collective Memory. Edited and translated by Lewis A. Coser. Chicago: University of Chicago Press, 1992.

Hammack, Phillip L. Narrative and the politics of identity: The cultural psychology of Israeli and Palestinian youth. New York, NY: Oxford University Press, 2011.

Heller, Agnes. European master narratives about freedom. In Handbook of contemporary European social theory, edited by Gerard Delanty, 257-265. New York, NY: Routledge, 2006.

Hobsbawm, Eric. Nations and nationalism since 1780: Programme, myth, reality. Cambridge: Cambridge University Press, 1990.

László, János. Historical tales and national identity: An introduction to narrative social psychology. New York, NY: Routledge, 2013.

Knell, Simon, Peter Aronsson, and Arne Bugge Amundsen eds. National Museums. New Studies from around the World. London: Routledge, 2011.

Koselleck, Reinhart. Futures past: On the semantics of historical time. New York, NY: Columbia University Press, 2004.

Lopez, Cesar, Mario Carretero, and María Rodriguez-Moneo. Conquest or reconquest? Students' conceptions of nation embedded in a historical narrative. Journal of the Learning Sciences (2014).

Lopez, Cesar, Mario Carretero, and María Rodriguez-Moneo. Telling a national narrative that is not your own. Does it enable disciplinary historical consumption? Cultuture \& Psychology 20, no. 4 (2014):547-571.

Monte-Sano, Chaunces. Disciplinary Literacy in History: An Exploration of the Historical Nature of Adolescents' Writing. Journal of the Learning Sciences 19, no. 4 (2010): 539-568.

Nussbaum, Martha C. and Joshua Cohen, eds. For Love of Country?: A New Democracy Forum on the Limits of Patriotism. Boston, MA: Beacon Press, 2002.

Reicher, Stephen and Nick Hopkins. Self and nation: Categorization, contestation and mobilisation. London: Sage Publishing, 2001.

Seixas, Peter, ed. Theorizing historical consciousness. Toronto: University of Toronto Press, 2004.

Seixas, Peter. National history and beyond. Journal of Curriculum Studies 41, no. 6 (2010): 719-722.

Sibley, Chris S., James H. Liu, John Duckitt, and Sammyh S. Khan. Social representations of history and the legitimation of social inequality: The form and function of historical negation. European Journal of Psychology 38, no. 3 (2008): 542-565. 
Smeekes, Anouk. The presence of the past. Historical rooting of national identity and current group dynamics. Doctoral dissertation, Utrecht University, 2014.

Straub, Jürgen, ed. Narration, identity, and historical consciousness. New York, NY: Berghahn Books, 2005.

Taylor, Tony and Robert Guyver. History Wars and the Classroom: Global Perspectives. Charlotte, North Carolina: Information Age Publishing, 2011.

Todorov, Tzvetan. The conquest of America: The question of the other. New York: Harper and Collins, 1999.

VanSledright, Bruce. Narratives of nation-state, historical knowledge and school history education. Review of Research in Education 32, no. 1 (2008): 109-146.

Wertsch, James V. Voices of Collective Remembering. Cambridge: Cambridge University Press, 2002.

Wineburg, Sam. Historical Thinking and Other Unnatural Acts. Philadelphia: Temple University Press, 2001.

Westheimer, Joel. Pledging allegiance: The politics of patriotism in America's schools. New York: Teachers College Press, 2007 